\section{Mentoring and skill development in e-Internships}

\author{
Debora Jeske and Carol Linehan \\ School of Applied Psychology, University College Cork, Cork, Ireland
}

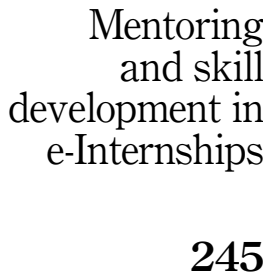

Received 26 September 2019 Revised 26 January 2020 26 February 2020

Accepted 26 February 2020

\begin{abstract}
Purpose - Many employers experiment with virtual working modes for project-based work. Virtual internships are one such mode that is gaining increasing popularity worldwide, particularly e-internships that require remote working with employers. However, little is known about the extent to which e-internships present learning opportunities to such e-interns.

Design/methodology/approach - The current study examined mentoring experiences among a crosssectional sample of 158 e-interns working for different companies. Data were collected using an online survey in two data collection rounds.

Findings - The length of the e-internships did not increase mentoring satisfaction, but the likelihood of einterns having a mentor was higher the longer the e-internships. Mentoring was offered irrespective of working hours per week. Mentoring increased reported skill development, particularly in relation to their communication skills and their ability to think strategically about problems. In addition, mentored e-interns were more likely to have opportunities to cooperate with and help others. They likewise had opportunities to share information, knowledge and experiences.

Research limitations/implications - The study recruited interns from various countries. Potentially relevant cultural differences were not explored as part of this study.

Practical implications - The results demonstrate that the benefits of mentoring observed in relation to traditional internships can be fostered in e-internships. E-internships represent an opportunity for managers and employees, regardless of company size, to become mentors. E-internships thus represent another workintegrated as well as work-applied learning and skill development opportunity that creates additional options for many interns and organisations alike.

Originality/value - The evidence suggests that mentoring is becoming a regularly available feature for virtual and temporary workers such as e-interns, many of which are hired for short-term projects. As remote working has become a standard practice, e-internships are on the rise - and worthy of further study in order to promote best practices.
\end{abstract}

Keywords Virtual internship, e-internship, Mentoring, Skill development

Paper type Research paper

\section{Introduction}

Remote working is becoming increasingly popular in the workplace (BLS, 2016). In 2015, 24\% of people in the USA did some or all of their work remotely. Many tools have become readily available in households, which means remote workers no longer need to have advanced technological skills to work from home (BLS, 2017). This has led to working remotely becoming a mainstream phenomenon - a phenomenon that appears to apply to internships. Today, e-internships (also known as virtual internships) are becoming popular across the globe, complementing remote employment trends.

(C) Debora Jeske and Carol Linehan. Published in Journal of Work-Applied Management. Published by Emerald Publishing Limited. This article is published under the Creative Commons Attribution (CC BY 4.0) licence. Anyone may reproduce, distribute, translate and create derivative works of this article (for both commercial and non-commercial purposes), subject to full attribution to the original publication and authors. The full terms of this licence may be seen at http://creativecommons.org/licences/by/4.0/ legalcode

Funding: The research was not funded by any agency or grant.

Disclosure statement: The authors are not aware of any conflict of interest.

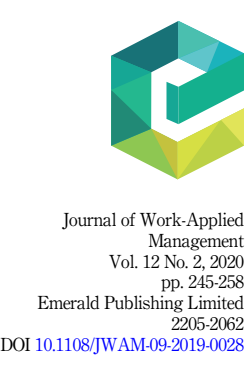


JWAM

12,2

246

In line with the emergence of teleworking and remote working models, new internship forms emerged. E-internships are partially or fully computer-mediated internships that are provided by an employer or institution to candidates (Bayerlein and Jeske, 2018, 2018b). While many e-internship schemes involve some in-person or face-to-face contact, the majority are largely or completely computer-mediated and allow for e-interns and organisations to be geographically separated (which means they can be located in the same or different countries, time zones and continents). Like traditional internships, e-internships are often open to candidates within educational programmes and as transitional experiences. However, unlike traditional internships, e-internships are correspondingly open to those outside education who wish to change careers at later stages of life (Jeske, 2019). This means that e-interns could be students, parents in part-time employment, or even experienced career professionals. Existing research suggests that e-internships are often adopted by smaller organisations who are not necessarily large enough to offer traditional internship positions (Jeske and Axtell, 2016a, b). While the majority of these e-internships tend to be taken up by individuals in the same region or country as the e-internship provider, many e-internships are global (Franks and Oliver, 2012; Jeske and Axtell, 2016a, b), especially when employers seek specific skill sets.

However, many employers and academics are aware that interns seek guidance, encouragement and help during their traditional internship experience, while they are hoping to be "given plenty of scope for experimentation, autonomy and learning during internship" (Neelam et al., 2019, p. 101). E-internships potentially provide room for experimentation, autonomy and learning. That said, we know little about the extent to which e-interns are guided and supported in their e-internships when they are not directly linked to educational institutions, like traditional internships. It is possible that mentors provide an important pillar of support to e-interns, similar to traditional interns. Therefore, the present paper aims to explore the following two research questions. First, to what extent do e-interns have access to mentoring during their e-internships. And second, does this mentoring contribute to their skill development?

\section{Mentoring in e-internships}

Mentoring is an important human resource development approach that can promote employee commitment (Ahmad and Bakur, 2003; Bartlett and Kang, 2004) and performance (Lin and Hsu, 2017). However, limited research to date has explored if mentoring exists in einternships, and the skill development that takes place in such temporary placements (Bayerlein and Jeske, 2018; Jeske and Axtell, 2016b; Ruggerio and Boehm, 2017). Research on mentoring has demonstrated numerous benefits such as mentors offering career guidance and psychosocial support to mentees (Haran and Jeyaraj, 2019). With their help and input, mentors enable mentees to quickly familiarize themselves with norms, strategies, and work approaches in their new settings. They can act as role models and as confidants (Haran and Jeyaraj, 2019; Mitchell et al., 2015; Parent and Olivier, 2015), providing suggestions on how to deal with issues in the workplace (Inkson et al., 2015).

Mentors play an important role in clarifying communication, reducing uncertainty and ambiguity. By doing so, they raise the expected value in the case of traditional internships (see Bhattacharya et al., 2018). Furthermore, the access to mentors - and thus potential role models - has been argued to promote skill transfer for graduates at work (Jackson, 2016). Internship value may similarly be promoted via behaviours by mentors such as sponsorship, raising the visibility of the mentee in the organisation, protecting them and giving them challenging assignments to support their development (Ensher et al., 2003).

In the e-internship context mentoring can be a useful alternative approach due to its flexibility, and the option to keep interactions informal and need-focused. The merit of 
informal (as in more individually agreed and flexible) mentoring arrangements has been demonstrated in a number of studies in the workplace (Singh et al., 2002), training programs (Cobb et al., 2018) and traditional internships (Chao et al., 1992). The informal and thus predominantly flexible and relationship-based nature of these e-internships may be more conducive to developing increasingly natural and rewarding relationships (Jeske and Axtell, 2018a), particularly when the e-internships are of longer duration (e.g. several months to a year) rather than very short (e.g. several weeks only). Lack of time is one of the factors that has been associated with dissatisfactory outcomes in mentoring (see Hansford et al., 2002). Of course, mentoring requires that organisations have staff to mentor e-interns and are available to support them during their e-internships.

This leads us to propose the following about the experience and benefits of e-mentoring generally (rather than formal or informal mentoring per se):

H1. Participants completing longer e-internships report having a mentor and higher satisfaction with the mentoring experience than participants who complete shortterm e-internships.

In an analysis of 26 studies on traditional internships, Feldman (2016) found that these internships contribute to personal, professional, and social skills. Other studies note improvements in cross-cultural and language skills (Bilsland et al., 2019), critical thinking, communication, and problem solving (Griffin and Coelhoso, 2019). Traditional internships likewise help interns to get insights into different career paths, assess career-fit and engage in career building (Attri and Kushwaha, 2018; Bilsland et al., 2019; Nghia and My Duyen, 2018). In the context of e-internships, mentors can offer feedback on skill development, counselling, friendship and encouragement (Ensher et al., 2003). We use the word mentor to define "a trusted advisor or confidant on whom another person (sometimes called the 'mentee' or 'protégé') relies for advice and support. In the context of careers, a mentor is normally understood as being an older, more experienced person who is able, on the basis of that experience, to provide help to a younger career actor in developing their career through its early stages" (Inkson et al., 2015, p. 229). Indeed, virtual mentorship schemes to support the development of preservice teachers and practicing teachers has shown that computermediated mentoring can promote confidence, commitment to, and knowledge about, one's job choice (Briscoe, 2019). In combination, e-internships featuring mentoring can be expected to generate higher skill development and opportunities than those that lack mentoring. This leads to the next hypothesis:

H2. Mentored interns are more likely to report skill development than interns who are not mentored during their e-internships.

Considering that mentoring can provide more information about one's job choice (e.g. Briscoe, 2019), we propose that mentoring can create a number of additional opportunities for einterns as they get exposed to more information about the role, the organisation, and their clients via their mentors. The third and final hypothesis therefore proposes the following:

H3. Mentored interns are more likely to report having access to additional opportunities to engage in contextual performance behaviours than those not mentored during their e-internships.

\section{Method}

Procedure

Following agreement on ethical requirements and a review of the proposed study by an institutional ethics committee, recruitment for the study took place over two time periods in 2013 and 2015. For both data collection rounds the first author emailed around 30
Mentoring and skill development in e-Internships 
JWAM

12,2

248

organisations advertising e-internships in the USA with an online survey link. In addition, e-interns were sought by advertising the study on two portals specialising in e-internships, one in the USA and another in India. The reason for focusing on these two portals was based on the fact that e-internships are well established among organisations in both these countries. Given that e-internships are not geographically bound (e.g. the company offering an e-internship and the e-intern do not have to be in the same country), participants were expected to represent any number of nationalities. The content of the online survey (using SurveyMonkey) included: Introduction to study purpose, request to consent, questions about the participants' background, the e-internship provider, information accuracy regarding information provided at the start of the e-internship, the mentoring experience, their skill development, working hours, and demographics.

\section{Participants}

The survey was started by 171 individuals. Due to missing data, the final sample included 158 participants (89 males and 68 females, 1 missing value). Age ranged from 16 to 50 (1 missing value). The large majority $(n=134)$ had completed the e-internship within five years of the survey (2011-2015), with 54 participants completing the survey in the same year as the e-internship. Participants came from several different countries, the majority from India $(n=127)$. The remainder $(n=31)$ came from a variety of different countries (USA, France, Nigeria, Russia, Brazil, Canada, Ethiopia, Guyana, Hungary, Ireland, Lithuania, Switzerland, and United Kingdom). This result is not surprising as e-interns are not required to be located in the same country as the e-internship providers. The large majority $(n=122)$ were still studying for a degree (or vocational certificate) at the time of the e-internship, but one in five was no longer in education. This accounts for the differences in age among participants. Three-quarters of providers were for-profit organisations. Others were non-profit and government organisations. All operated in sectors such as IT \& Telecommunications; Advertising, Marketing and Public Relations; Education; and Banking and Financial Services. The majority of participants $(n=123)$ worked in teams where there were other virtual team members. The organisations where e-interns completed their e-internships tended to be smaller. Forty-one (25.9\%) participants worked in companies with up to 20 employees, another $25(15.8 \%)$ participants worked in companies with up to 49 employees. Middle-sized organisations were similarly represented among e-internship providers, including organisations with up to 199 employees $(n=29,18.4 \%)$, and even up to 500 employees $(n=18,11.4 \%)$. A quarter worked for large organisations with more than 500 employees ( $n=37,23.4 \%$; 8 missing cases). In addition, 46 participants $(29.1 \%)$ worked with a company located in a different country.

\section{Measures}

The survey included several sections, covering characteristics of the work context (e.g. hours, team composition), and e-internship, the e-internship experience, and mentoring.

Information accuracy. This was measured using one item "How accurate was the einternship information you had before you started the e-internship?" Responses ranged from (1) "not at all" to (5) "to a very great extent" $(M=3.57, S D=0.83)$.

Mentoring experience. This included several measures. (1) Mentoring available. We asked participants if they received mentoring. In order to provide all participants with a common frame of reference, we defined mentoring as follows (derived from a definition of mentoring provided by Hansford et al., 2002): "We consider mentoring as a personal, helping relationship between a mentor and a mentee/protégé that includes professional development and growth and varying degrees of support. While mentoring relationships are reciprocal, mentors tend to be those with greater experience." Participants were asked the following: "I had a mentor 
(somebody who counsels you during your e-internship, helping you improve your skills and become familiar with organisational functions). This may be a supervisor, a colleague, or another experienced third party (e.g. another manager)." This meant mentoring in this study can encompass both formal and informal mentoring (more or less structured mentoring). Participants were presented with a dichotomous response option: Yes $(n=107,67.7 \%)$ and No $(n=51,32.3 \%$ ). We considered (2) Satisfaction with mentoring (overall). This was assessed using one item. Participants were asked "How satisfied were you with the mentoring you received during the e-internship?" Response options ranged from (1) "very unsatisfied" to (4) "very satisfied" $(M=2.95, S D=0.60)$.

Skill development. We used four items to learn about skill development, based on Szymanski et al. (2007), subject to minor modifications. Participants were asked to indicate which apply. These were: (a) "I developed my interpersonal skills"; (b) "I improved my communication skills"; (c) "I learned how to think strategically about problems", and (d) "I learned new skills that are important for my career development". The response options were dichotomous ("Yes" and "No").

Contextual performance. All participants were asked three questions that capture contextual performance (modified from Borman and Motowidlo, 1993; Lee et al., 2010). The items were: "Did you have the opportunity to" followed by the item stem: (a) "Volunteer to extra activities?", (b) "Help and cooperate with others?", and (c) "Share job related information, knowledge, and experience with other co-workers?". Response options included "Yes" and "No".

Feedback adequacy. All e-interns were asked to respond to a statement "I was given adequate feedback regarding how I was doing". Response options ranged from (1) "strongly disagree" to (4) "strongly agree" $(M=3.04, S D=0.61)$.

Working hours. All participants were asked to report how many hours they tended to work per week during their e-internships. Sixty-five e-interns worked up to $10 \mathrm{~h} /$ week (41.1\%), 45 worked up to $20 \mathrm{~h} /$ week $(28.5 \%), 29$ worked up to $30 \mathrm{~h} /$ week $(18.4 \%)$. A small number worked more hours, such as up to $40 \mathrm{~h} /$ week $(n=13,8.2 \%), 50 \mathrm{~h} /$ week $(n=5,3.2 \%)$ and one participant worked more than $50 \mathrm{~h} /$ week.

Demographics. Demographics included information on gender, age, nationality and disability. One participant reported that they had a disability that affects their ability to commute/travel unaided, while two participants reported that they had a disability that affected their ability to use/work on a computer without additional adjustments.

\section{Results}

Scale correlations

Information accuracy, in terms of the information being made available about the einternship prior to starting, correlated with e-intern's mentoring satisfaction $(r=0.21$, $p=0.032)$ and feedback adequacy $(r=0.25, p=0.002)$. Mentoring satisfaction correlated with feedback adequacy $(r=0.31, p=0.001)$. Age was not correlated with any of these measures. There were no significant differences between the Indian and the non-Indian respondents in relation to mentoring satisfaction. Payment did not affect this variable.

\section{Hypothesis 1}

The first hypothesis suggested that participants completing longer e-internships will report higher satisfaction with mentoring than participants who complete short-term e-internships (H1). We compared the satisfaction rates based on e-internship length only for those e-interns who were actually mentored. The analysis therefore focused on 93 (out of 158 participants) who were mentored, and categorised length of e-internship into three time periods. 
JWAM

12,2

250

Descriptive statistics (Table 1) indicate that this was not the case as the mean satisfaction values were very similar for all three groups. However, the length of an e-internship did appear to affect the likelihood of having a mentor, with $56 \%$ of those in the shortest e-internships reporting having a mentor versus $76 \%$ of those in 3-12 months e-internships (Table 1).

In further exploratory analyses, we examined whether interns are more or less likely to be mentored when the e-internship involves cross-boundary features compared to those who worked with organisations in their own region or from their own culture. E-interns who had cross-boundary e-internships actually were more likely to have a mentor $\left(\chi^{2}(1)=5.66\right.$, $p=0.017 ; p h i=0.19$ ). In addition, those who worked with organisations across boundaries were not more likely to be paid than e-interns who worked with providers in their own region/ from their own culture. Mentoring (being mentored or not) did not play a role in terms of whether or not e-interns were paid, in line with research by McHugh (2016).

One additional analysis was conducted to examine if working hours increased the likelihood of e-interns being offered mentoring. The hypothesis was tested using Chi square. Results suggested that the likelihood of an e-intern receiving mentoring $\left(\chi^{2}(3)=2.88\right.$, $p=0.410$ ) was not related to the amount of time spent working for an employer each week. In other words, mentoring had been made available to e-interns to a similar degree, regardless of working hours.

\section{Hypothesis 2}

Skill development was the focus of the second hypothesis. In our sample, 82 out of 158 e-interns $(52 \%)$ reported that they had developed their interpersonal skills, $83(53 \%)$ had improved their communication skills, $96(61 \%)$ learned how to think strategically and 105 $(66 \%)$ said they learned skills important for career development.

The second hypothesis proposed that mentored interns are more likely to report skill gains than interns who are not mentored during their e-internships (H2). In this case, the answers to four different items were examined (Table 2).

The relationship between mentoring and skill development was examined using Chi square as this was deemed the most appropriate option to analyse categorical data. This statistic evaluates if a relationship exists between mentoring and skill development, but does not indicate how strong this relationship is. However, the Phi coefficient provides an effect size (for $2 \times 2$ tables). The results for the four analyses (one for each item on skill development) are summarized in Table 2 . As predicted, mentored participants $(n=107)$ reported a significantly greater skill gain in relation to communication skills and strategic problem solving skills than those e-interns who were not mentored $(n=51)$. The level of association as indicated by Phi tended to be weak but acceptable (range from -0.15 to -0.19 ). This provides support for $\mathrm{H} 2$ that mentoring can support skill gain in relation to communication and strategic problem solving skills in particular. The results match the results of a $t$-test conducted with feedback adequacy $(t=2.63, p=0.010)$. Mentored e-interns agreed significantly more strongly with the statement that they received adequate feedback

Table 1.

Length of e-internship (most recent) of mentees
Mentoring satisfaction of mentees Scale $M(\mathrm{SD})$

Length of e-internship

$2.89(0.58)$

up to 6 weeks $(n=27)$

$3.02(0.59)$

6-12 weeks $(n=43)$

$2.91(0.73)$

Mean

$2.96(0.63)$

Note(s): $n=93$ instead of 107 due to missing information. $M=$ Mean, $\mathrm{SD}=$ Standard deviation 


\begin{tabular}{|c|c|c|c|c|}
\hline Personal growth items & $\begin{array}{l}\text { Answers } \\
(\text { total } N)\end{array}$ & $\begin{array}{l}\text { Mentored } \\
\text { Obs (exp) }\end{array}$ & $\begin{array}{l}\text { cy count } \\
\text { Not } \\
\text { mentored } \\
\text { Obs (exp) }\end{array}$ & Statistics \\
\hline I developed my interpersonal skills & $\begin{array}{r}\text { Yes (92) } \\
\text { No (76) }\end{array}$ & $\begin{array}{l}61(55.5) \\
46(51.5)\end{array}$ & $\begin{array}{l}21(26.5) \\
30(24.5)\end{array}$ & $\begin{array}{c}\chi^{2}(1)=3.47 p=0.063 \\
\text { phi } i=-0.15\end{array}$ \\
\hline $\begin{array}{l}\text { I improved my communication } \\
\text { skills* }\end{array}$ & $\begin{array}{r}\text { Yes (83) } \\
\text { No (75) }\end{array}$ & $\begin{array}{l}63(56.2) \\
44(50.8)\end{array}$ & $\begin{array}{l}20(26.8) \\
31(24.2)\end{array}$ & $\begin{array}{c}\chi^{2}(1)=5.35 p=0.021 \\
\text { phi }=-0.18\end{array}$ \\
\hline $\begin{array}{l}\text { I learned how to think strategically } \\
\text { about problems* }\end{array}$ & $\begin{array}{r}\text { Yes }(96) \\
\text { No }(62)\end{array}$ & $\begin{array}{l}72(65.0) \\
35(42.0)\end{array}$ & $\begin{array}{l}24(31.0) \\
27(20.0)\end{array}$ & $\begin{array}{c}\chi^{2}(1)=5.93 p=0.015 \\
\text { phi }=-0.19\end{array}$ \\
\hline $\begin{array}{l}\text { I learned new skills . . f for my career } \\
\text { development }\end{array}$ & $\begin{array}{l}\text { Yes (105) } \\
\text { No (53) }\end{array}$ & $\begin{array}{l}66(71.1) \\
41(35.9)\end{array}$ & $\begin{array}{l}39(33.9) \\
12(17.1)\end{array}$ & $\begin{array}{c}\chi^{2}(1)=3.39 p=0.066 \\
p h i=0.15\end{array}$ \\
\hline
\end{tabular}

Note(s): $N=158$. *significant result $p<0.05$. The first number represents the observed count (Obs), the number in the bracket represents the expected count (Exp). Likelihood analysis results include Pearson Chi Square and asymptotic significant (2-sided). Some missing values

Mentoring and skill development in e-Internships

Table 2 Mentoring and skill development

$(M=3.13, S D=0.58, n=107)$ compared to those e-interns who were not mentored $(M=2.86$, $S D=0.53, n=51)$.

\section{Hypothesis 3}

The extent to which e-interns had the opportunity to engage in contextual performancerelated tasks was the focus of the third hypothesis. In our sample, 90 out of 158 e-interns $(57 \%)$ confirmed that they got a chance to volunteer for extra activities, $96(61 \%)$ had a chance to help and cooperate with others, and $92(58 \%)$ could share job-related information, knowledge and experience with other co-workers.

The third hypothesis proposed that mentored interns are more likely to report having additional opportunities (H3). We used the same approach as in relation to H2. The results (Table 3) confirmed that mentored e-interns had more opportunities to help out and cooperate with others, and likewise had more opportunities in their e-internship to share information, knowledge, and experience with co-workers. The degree to which e-interns could share information was not related to whether or not they were the only one working virtually in their team. This confirms the merit of mentoring and supports the premise that mentors may create additional opportunities for their e-interns.

\begin{tabular}{lcccc}
\hline & \multicolumn{4}{c}{ Expectancy count } \\
& $\begin{array}{c}\text { Not } \\
\text { Answers } \\
\text { Opportunities }\end{array}$ & $\begin{array}{c}\text { Mentored } \\
\text { mentored }\end{array}$ & Statistics \\
\hline Volunteering & Yes (90) & $62(60.6)$ & $28(29.4)$ & $\chi^{2}(1)=0.24, p=0.621 ;$ \\
& No (63) & $41(42.4)$ & $22(20.6)$ & $p h i=0.04$ \\
Helping out/co-operating & Yes (96) & $71(64.8)$ & $25(31.2)$ & $\chi^{2}(1)=4.80 p=0.028 ;$ \\
& No (58) & $33(39.2)$ & $25(18.8)$ & phi 0.18 \\
Sharing info/knowledge/ & Yes (92) & $70(61.9)$ & $22(30.1)$ & $\chi^{2}(1)=8.06 p=0.005 ;$ \\
experience with co-workers & No (61) & $33(41.1)$ & $28(19.9)$ & $p h i=0.23$
\end{tabular}

Note(s): $N=158 . *$ significant result $p<0.05$. The first number represents the observed count (Obs), the number in the bracket represents the expected count (Exp). Likelihood analysis results include Pearson Chi Square and asymptotic significant (2-sided). Some missing values

Table 3.

Mentoring and additional opportunities 
JWAM

12,2

\section{Discussion}

The goal of the current paper was to examine the occurrence, experience and outcomes of mentoring in e-internships. The following section provides a short summary of findings in line with the hypotheses, followed by a discussion of limitations and future research. The paper concludes with a discussion of practical implications and recommendations for practitioners and those interested in implementing e-internships.

In overall terms, two-thirds of e-interns (107) reported that they were supported by mentors who facilitated their professional development, growth and provided varying degrees of help. Furthermore, more than half of the interns - whether mentored or not reported skills gains which were also noted as outcomes in traditional internships (Feldman, 2016; Griffin and Coelhoso, 2019; Kapareliotis et al., 2019). This confirms the proposition that e-internships - like traditional internships - can promote skill development, as suggested by Bayerlein and Jeske (2018). In short, e-internships provide a new opportunity to study workapplied learning outside educational settings and within organisational settings, thus expanding our understanding of work-based and work-applied learning in organisational settings as discussed in the works by Critten (2016) and Garnett et al. (2016).

Three hypotheses were examined. The first hypothesis proposed that length of e-internships would be related to satisfaction with the mentoring received by participants (H1). However, H1 was not supported. Mentoring satisfaction was not subject to the length of the e-internship. Additional exploratory analyses suggested that e-interns who had crossboundary e-internships actually tended to be more - not less-likely to be mentored. On the one hand, it is possible that higher growth-need strength (a moderator suggested by Hackman and Oldham, 1980) increased mentoring satisfaction among all mentees, regardless of the length of the e-internship. On the other hand, the results suggest that the relationship with the mentor is more important than the length of the e-internship. This is in line with the suggestion by Kuh (2008) who proposed that in order for traditional internships to be impactful, interns need to have the opportunity to have, and develop, relationships with those who share their interests. The mentoring that our e-interns received has potentially fulfilled this function. Furthermore, mentors can support goal setting and achievement. This would be in line with work that has shown that the "perceived value of the supervisor-intern exchange has a significant relationship with perceived internship value" (Neelam et al., 2019, pp. 92).

The second hypothesis suggested that mentored interns are more likely to report skill gains than interns who are not mentored during their e-internships (H2). This hypothesis was supported, particularly in relation to communication and strategic thinking about problems. These results align with evidence from other studies that have shown that mentors can help mentees to improve their critical thinking (Griffin and Coelhoso, 2019) and people and communication skills (Barnett et al., 2017). Additionally, mentees have more opportunity to address communication issues and get advice on how to tackle problems strategically compared to their peers who were not mentored.

The third hypothesis reflected the premise of the second hypothesis in that mentors create additional learning opportunities (H3). Two-thirds of those who were mentored had more chance to help and cooperate with others. Furthermore, a similar number of mentored einterns were able to share information, knowledge and experience with co-workers. These findings also indicate that mentoring in e-internships can generate additional opportunities to work and engage with others. This links to other work that found mentoring can positively contribute to knowledge sharing (Burnette, 2017) and increase networking opportunities for e-interns as well as traditional interns (Bilsland et al., 2019; Cohen, 2014; Nghia and My Duyen, 2018), thus raising the visibility of the mentee in the organisation (Ensher et al., 2003).

The correlations between information accuracy, feedback adequacy and mentoring satisfaction reflect the importance of setting accurate expectations. Prior research has shown that when interns have a clear understanding of what they need to achieve, they are more 
likely to be both effective and satisfied (Kapareliotis et al., 2019). The lower the discrepancy between internship expectations and the actual experience, the higher interns' satisfaction (Neelam et al., 2019). This suggests that communication before and during the internship (e.g. with the help of a mentor) can make a significant difference to interns' experience, which in turn, may promote skill development among e-interns.

In summary, our research suggest that e-internships lead to skill development, particularly when e-interns are supported by mentors - even when e-internships are relatively short (e.g. a few weeks rather than several months). The next section provides an overview of practical points that address managerial practices and outline the potential benefits of mentoring for organisations wishing to adopt e-internship schemes.

\section{Practical implications}

Mentoring can be a very appropriate option for many organisations for a number of reasons. Mentoring enables supervisors to personalize support to e-interns, allowing them to focus on strengths, career advice, and developmental areas. Offering training that assumes a one-sizefits-all may not be as effective as mentoring (especially when the business is small and does not have traditional or e-internship coordinators or trainers), in terms of the costs involved or the motivational potential that mentoring has for e-interns seeking direction on the job and in their career.

On a practical level, organisations can construct their e-internships independently from educational requirements. Many educational providers require curriculum alignment (Metso and Kianto, 2014), which means that traditional internships often need to fit academic timelines and meet certain skill gaps to complement what is taught in higher education. However, such alignment may be an option - not a requirement - if employers decide to offer e-internships that are not tied to an academic curriculum or credit system.

Interestingly, some reciprocal effects can emerge, as the learning experience is not limited to the e-interns (Jeske and Axtell, 2018b). Their supervisors learn from their interns and benefit, for example, via activities that involve the co-construction and exchange of knowledge (Bello and Mansour, 2013; Jeske and Axtell, 2016a, b; Ruggerio and Boehm, 2017). Mentoring offers supervisors the opportunity to learn from interns about different perspectives and trends (Bhattacharya and Neelam, 2018). Especially when cross-cultural elements come into play, mentoring can help supervisors and e-interns to discover and clarify different cultural expectations. The interactions that are part of mentoring may thus create a mutually beneficial channel of communication to clarify expectations, reduce uncertainty and increase traditional and e-internship value (Bhattacharya and Neelam, 2018; Griffin and Coelhoso, 2019). Having mentors benefits organisations by reducing silent drop-out, which is important as dropping out of an e-internship is significantly easier than leaving a traditional internship.

Numerous resources such as online resources are available to support managers, even those in small and non-profit businesses, who wish to offer mentoring and training at work even for very short periods of time (Hamori, 2019; Hughes et al., 2018). A number of international organisations (e.g. The European Mentoring and Coaching Council) provide information online. In addition, several relevant resources have been published that can be consulted by employers wishing to adopt mentoring schemes (e.g. The SAGE Handbook of Mentoring by Clutterbuck et al., 2017). Particularly worth mentioning is the Virtual Mentoring case Model by Owen and Whalley (2017), as this is a framework for virtual mentoring.

\section{Limitations and future research}

A number of methodological limitations apply. First, the study relied on interns in different national settings. Cultural variables were not the focus of the survey, although these have
Mentoring and skill development in e-Internships 
JWAM

12,2

played a role and ought to be considered in future studies. Indeed, more work to examine the specific aspects that support or inhibit mentoring success may be worth pursuing to gain an in-depth understanding of the dynamics behind cross-boundary differences and mentoring. In addition, we did not have a comparison group of interns who work at physical locations (e.g. a control group completing traditional internships in the same organisations) to be able to determine how different the respondents' experiences are from interns who had a comparable face-to-face experience.

The diversity was the result of the sampling, as we did not restrict sampling to participants in either India or the USA alone, but kept the survey open to anybody who completed an e-internship. However, the experience of the largely Indian sample is worthwhile exploring. Indeed, a large number of articles of late have studied the experience of Indian students in traditional internships where these internships are seen as critical to ensure that graduates become job-ready (Attri and Kushkaha, 2018; Bhattacharya and Neelam, 2018). Particularly developing countries and large economies such as India and China, but also countries such as Australia, are struggling to provide traditional internship opportunities to increasing numbers of students (Chand and Deshmukh, 2019). This could explain the rising attractiveness of e-internships and investments in entirely simulated internships (Bayerlein and Jeske, 2018) in countries such as India (see Chand and Deshmukh, 2019). This might explain the popularity of both traditional and computer-mediated internships, including the high participation rates of Indian participants in this survey.

And second, the study did not include a measure of similarity between mentors and mentees (or mentor-mentee fit). This was a potential control variable as Allen and Eby (2003) showed that when mentors were perceived to be similar to mentees, mentees reported that the mentoring relationship was of higher quality and resulted in more learning. Similarly, we did not differentiate between formal or informal mentoring, but based all reports on the dichotomous agreement of our participants to our definition of mentoring. In addition, we did not include a measure regarding the frequency with which mentors and mentees met during their e-internships. More frequent and regular interactions support the development of mentoring relationships over time (Bierema and Merriam, 2002). The results we reported here were collected between 2013 and 2015. However, we argue that the findings around mentoring remain relevant given the emergence of more and more interactive tools that can support mentoring and the increasing presence of e-internships today across many different continents.

At a conceptual level, two limitations should be mentioned. In the present study, mentoring was not differentiated in terms of its perceived temporary or long-term merit (e.g. career or psychosocial), but only examined mentoring effects overall. The magnitude of benefits depends on the kind of mentoring individuals receive (Allen et al., 2004). And finally, the research focused only on skill-based outcomes, not cognitive and affective outcomes. Considering all three dimensions of training in the context of e-internships may generate more comprehensive insights into the dynamics that determine which learning outcomes are achieved. Additionally, limitations pertain to the reliance on self-report and the use of descriptive variables (e.g. skill development).

Two final areas requiring more research should be mentioned. First, there is a general lack of information on the prevalence rate of e-internships across various countries (the schemes are currently particularly prominent in India and the USA). By extension, no work has examined the experience of e-interns in relation to cross-cultural differences and how this might influence their satisfaction with mentors. Second, there is a dearth of potential theoretical frameworks available that consider the psychosocial and technological predictors of learning outcomes in computer-mediated training and mentoring situations.

A number of models can be used to explore the influence of technology on personal interactions and skill gain in e-internships in future studies. The Technology Assistance 
Model considers perceived usefulness and ease of use of information technology (see Davis, 1989). The Technology Acceptance Model has already been applied to e-learning (Abdullah and Ward, 2016). An application to e-mentoring in combination with another model may be the way forward. The United Theory of Acceptance and Use of Technology (e.g. Venkatesh et al., 2003) considers factors such as performance and effort expectancies, social influence and facilitation conditions as predictor of intention and technological use behaviours. A combination of these models, in concert with considering the growth and relatedness needs (see Hackman and Oldham (1980), might provide a start towards a theory of work-based learning (e.g. mentoring and training) among adults in computer-mediated settings.

\section{References}

Abdullah, F. and Ward, R. (2016), "Developing a general extended technology acceptance model for Elearning (GETAMEL) by analysing commonly used external factors", Computers in Human Behavior, Vol. 56, pp. 238-256.

Ahmad, K.Z. and Bakar, R.A. (2003), "The association between training and organizational commitment among white-collar workers in Malaysia”, International Journal of Training and Development, Vol. 7 No. 3, pp. 166-185.

Allen, T.D. and Eby, L.T. (2003), "Relationship effectiveness for mentors: factors associated with learning and quality", Journal of Management, Vol. 29 No. 4, pp. 469-486.

Allen, T.D., Eby, L.T., Poteet, M.L., Lentz, E. and Lima, L. (2004), "Career benefits associated with mentoring for protégés: a meta-analysis", Journal of Applied Psychology, Vol. 89 No. 1, pp. 127-136.

Attri, R. and Kushwaha, P. (2018), "Enablers for good placements of graduates: fitting industry's needs", Higher Education, Skills and Work-Based Learning, Vol. 8 No. 4, pp. 544-556.

Barnett, B., Shoho, A. and Okilwa, N. (2017), "Assistant principals' perceptions of meaningful mentoring and professional development opportunities", International Journal of Mentoring and Coaching in Education, Vol. 6 No. 4, pp. 285-301.

Bartlett, K. and Kang, D. (2004), "Training and organizational commitment among nurses following industry and organizational change in New Zealand and the United States", Human Resource Development International, Vol. 7 No. 4, pp. 423-440.

Bhattacharya, S. and Neelam, N. (2018), "Perceived value of internship experience: a try before you leap", Higher Education, Skills and Work-Based Learning, Vol. 8 No. 4, pp. 376-394.

Bayerlein, L. and Jeske, D. (2018), "Student learning opportunities in traditional and computermediated internships", Education + Training, Vol. 60 No. 1, pp. 27-38.

Bello, M.A. and Mansor, Y. (2013), "Strengthening professional expertise: mentoring in knowledge transfer, the cataloguers' perspective", International Information and Library Review, Vol. 45 Nos 3-4, pp. 139-148.

Bierema, L.L. and Merriam, S.B. (2002), "E-mentoring: using computer mediated communication to enhance the mentoring process", Innovative Higher Education, Vol. 26 No. 3, pp. 211-227.

Bilsland, C., Carter, L. and Wood, L. (2019), "Work integrated learning internships in transnational education: alumni perspectives from Vietnam”, Education + Training, Vol. 61 No. 3, pp. 359-373.

BLS (2016), "24 Percent of employed people did some or all of their work at home in 2015", TED: The Economics Daily, published 8 July 2016. available at: https:/www.bls.gov/opub/ted/2016/ 24-percent-of-employed-people-did-some-or-all-of-their-work-at-home-in-2015.htm (accessed 26 September 2019).

BLS (2017), "Working alone: jobs that required little personal interaction in 2017", TED: The Economics Daily, published 6 December 2017. available at: https://www.bls.gov/opub/ted/ 2017/working-alone-jobs-that-required-little-personal-interaction-in-2017.htm (accessed 26 September 2019).
Mentoring and skill development in e-Internships 
JWAM

12,2

Borman, W.C. and Motowidlo, S.J. (1993), "Expanding the criterion domain to include elements of contextual performance", in Schmitt, N. and Borman, W.C. (Eds), Personnel Selection in Organizations, Jossey-Bass, San Francisco, pp. 71-98.

Briscoe, P. (2019), "Virtual mentor partnerships between practising and preservice teachers: helping to enhance professional growth and well-being", International Journal of Mentoring and Coaching in Education, Vol. 8 No. 4, pp. 235-254.

Burnette, M. (2017), “Tacit knowledge sharing among library colleagues: a pilot study", Reference Services Review, Vol. 45 No. 3, pp. 382-397.

Chand, V. and Deshmukh, K. (2019), "Addressing the undergraduate internship challenge in developing countries: a 'learning-by-doing' project-based online internship model”, Education + Training, Vol. 61 No. 9, pp. 1064-1077.

Chao, G.T., Walz, P.M. and Gardner, P.D. (1992), "Formal and informal mentorships: a comparison of mentoring functions and contrast with nonmentored counterparts", Personnel Psychology, Vol. 45 No. 3, pp. 619-636.

Clutterbuck, D.A., Kochan, F.K., Unsford, L., Dominguez, N. and Haddock-Millar, J. (Eds) (2017), The SAGE Handbook of Mentoring, Sage Publications, London.

Cobb, C.L., Zamboanga, B.L., Xie, D., Schwartz, S.J., Meca, A. and Sanders, G.L. (2018), "From advising to mentoring: toward proactive mentoring in health service psychology doctoral training programs", Training and Education in Professional Psychology, Vol. 12 No. 1, pp. 38-45.

Cohen, S. (2014), "Some thoughts on the importance of internships as part of an undergraduate program”, available at: www.amstat.org/asa/files/pdfs/EDU-Internships.pdf (accessed 18 January 2020).

Critten, P. (2016), "A radical agenda for enabling organisation transformation through work-applied learning", Journal of Work-Applied Management, Vol. 8 No. 1, pp. 65-78.

Davis, F.D. (1989), "Perceived usefulness, perceived ease of use, and user acceptance of information technology”, MIS Quarterly, Vol. 13 No. 3, pp. 319-339.

Ensher, E.A., Heun, C. and Blanchard, A. (2003), "Online mentoring and computer-mediated communication: new directions in research", Journal of Vocational Behavior, Vol. 2 No. 63, pp. 264-288.

Feldman, L. (2016), "Considerations in the design of WBL settings to enhance students' employability: a synthesis of individual and contextual perspectives", Higher Education, Skills and WorkBased Learning, Vol. 6 No. 2, pp. 131-145.

Franks, P.C. and Oliver, G.C. (2012), "Experiential learning and international collaboration opportunities: virtual internships", Library Review, Vol. 61 No. 4, pp. 272-285.

Garnett, J., Abraham, S. and Abraham, P. (2016), "Using work-based and work-applied learning to enhance the intellectual capital of organisations", Journal of Work-Applied Management, Vol. 8 No. 1, pp. 56-64.

Griffin, M. and Coelhoso, P. (2019), "Business students' perspectives on employability skills post internship experience: lessons from the UAE", Higher Education, Skills and Work-Based Learning, Vol. 9 No. 1, pp. 60-75.

Hackman, J.R. and Oldham, G.R. (1980), Work Redesign, Pearson Education, Upper Saddle River, NJ.

Hamori, M. (2019), "MOOCs at work: what induces employer support for them?”, The International Journal of Human Resource Management, Published online on 21 May 2019, doi: 10.1080/ 09585192.2019.1616593.

Hansford, B., Tennent, L. and Ehrich, L.C. (2002), "Business Mentoring: help or hindrance?", Mentoring and Tutoring, Vol. 10 No. 2, pp. 101-115.

Haran, V.V. and Jeyaraj, A. (2019), "Organizational e-mentoring and learning: an exploratory study", Information Resources Management Journal, Vol. 32 No. 1, pp. 58-72.

Hughes, A.M., Zajac, S., Spencer, J.M. and Salas, E. (2018), “A checklist for facilitating training transfer in organizations", International Journal of Training and Development, Vol. 22 No. 4, pp. 334-345. 
Inkson, K., Dries, N. and Arnold, J. (2015), Understanding Careers, 2nd ed., Sage, London.

Jackson, D. (2016), "Modelling graduate skill transfer from university to the workplace", Journal of Education and Work, Vol. 29 No. 6, pp. 199-231.

Jeske, D. (2019), "Virtual internships: learning opportunities and recommendations", in Shindell, R. (Ed), Total Internship Management - the Employer's Guide to Building and Sustaining the Ultimate Internship Program, 3rd ed., Intern Bridge, Cedar Park, Texas.

Jeske, D. and Axtell, C.M. (2016a), "Global in small steps: e-internships in SMEs", Organizational Dynamics, Vol. 45 No. 1, pp. 55-63.

Jeske, D. and Axtell, C.M. (2016b), "How to run successful e-internships: a case for organizational learning", Development and Learning in Organizations: An International Journal, Vol. 30 No. 2 , pp. 18-21.

Jeske, D. and Axtell, C.M. (2018a), "The nature of relationships in e-internships: a matter of psychological contract, communication and relational investment", The Journal of Work and Organizational Psychology, Vol. 34 No. 2, pp. 113-121.

Jeske, D. and Axtell, C.M. (2018b), "Virtuality in e-internships: a descriptive account", in Lazazzara, A., Nacamulli, R.C.D., Rossignoli, C. and Za, S. (Eds), Organizing in the Digital Economy. At the Interface between Social Media, Human Behaviour and Inclusion, Lecture Notes in Information Systems and Organisation (LNISO), Springer International Publishing, Cham.

Kapareliotis, I., Voutsina, K. and Patsiotis, A. (2019), "Internship and employability prospects: assessing student's work readiness", Higher Education, Skills and Work-Based Learning, Vol. 9 No. 4, pp. 538-549.

Kuh, G.D. (2008), High-Impact Educational Practices: What They Are, Who Has Access to Them, and Why They Matter. Association of American Colleges and Universities, Washington, DC.

Lee, Y.-H., Yang, L.-S., Wan, K. and Chen, G.-H. (2010), "Interactive effects of personality and friendship networks on contextual performance", Social Behavior and Personality, Vol. 38 No. 2, pp. 197-208.

Lin, S.R. and Hsu, C.C. (2017), "A study of impact on-job training on job performance of employees in catering industry", International Journal of Organizational Innovation, Vol. 9 No. 3, pp. 125-138.

McHugh, P.P. (2016), "The impact of compensation, supervision and work design on internship efficacy: implications for educators, employers and prospective interns", Journal of Education and Work, Vol. 30 No. 4, pp. 367-382.

Metso, S. and Kianto, A. (2014), "Vocational students' perspective on professional skills workplace learning”, Journal of Workplace Learning, Vol. 26 No. 2, pp. 128-148.

Mitchell, M.E., Eby, L.T. and Ragins, B.R. (2015), "My mentor, my self: antecedents and outcomes of perceived similarity in mentoring relationships", Journal of Vocational Behavior, Vol. 89, pp. 1-9.

Neelam, N., Bhattacharya, S., Kejriwal, V., Bhardwaj, V., Goyal, A., Saxena, A., Dhawan, D., Vaddi, A. and Choudaha, G. (2019), "Internship in a business school: expectation versus experience", Higher Education, Skills and Work-Based Learning, Vol. 9 No. 1, pp. 92-106.

Nghia, T. and My Duyen, N. (2018), "Internship-related learning outcomes and their influential factors: the case of Vietnamese tourism and hospitality students", Education + Training, Vol. 60 No. 1, pp. 69-81.

Owen, H. and Whalley, R. (2017), "A journey from within: the virtual mentoring CASE model”, Journal of Advances in Education Research, Vol. 2 No. 4, pp. 253-264.

Parent, M.C. and Oliver, J.A. (2015), "Mentoring the earliest-career psychologists: role models, knowledge of internship issues, and attitudes toward research and science”, Professional Psychology: Research and Practice, Vol. 46 No. 1, pp. 55-61.

Ruggerio, D. and Boehm, J.D. (2017), "Project-based learning in a virtual internship programme: a study of the interrelated roles between intern, mentor and client", Computers \& Education, Vol. 110, pp. 116-126. 
JWAM

12,2
Singh, V., Bains, D. and Vinnicombe, S. (2002), "Informal mentoring as an organisational resource", Long Range Planning, Vol. 35 No. 4, pp. 389-405.

Szymanski, D.M., Jovanovic Ozegovic, J., Phillips, J.C. and Briggs-Phillips, M. (2007), "Fostering scholarly productivity through academic and internship research training environments", Training and Education in Professional Psychology, Vol. 1 No. 2, pp. 135-146.

Venkatesh, V., Morris, M.G., Davis, G.B. and Davis, F.D. (2003), "User acceptance of information technology: toward a unified view”, MIS Quarterly, Vol. 27 No. 3, pp. 425-478.

\section{Corresponding author}

Debora Jeske can be contacted at: d.jeske@ucc.ie

For instructions on how to order reprints of this article, please visit our website: www.emeraldgrouppublishing.com/licensing/reprints.htm Or contact us for further details: permissions@emeraldinsight.com 